DOI 10.18551/rjoas.2021-11.06

\title{
THE ROLE OF FINANCIAL DISTRESS AS MEDIATOR BETWEEN FINANCIAL PERFORMANCE AND FIRM VALUE
}

\author{
Andari Ni Made Meliani ${ }^{\star}$, Rahyuda Henny \\ Faculty of Economics and Business, University of Udayana, Bali, Indonesia \\ *E-mail: melianiandari@gmail.com
}

\begin{abstract}
This study aims to determine the role of financial distress as a mediator between corporate financial performance and firm value. This research was conducted in mining companies listed on the Indonesia Stock Exchange in 2014-2019. This study uses quantitative research with an associative research design. The samples used were 26 mining companies. Determination of the sample completed using purposive sampling technique and path analysis technique. The results of this study indicate that financial distress is not able to mediate the effect of capital structure on firm value and operational efficiency on firm value. The practical implication that can be given from the results of this research is can be used as consideration for mining companies in determining the level of capital structure that takes into account the balance between benefits and costs, beside that sees the level of operational efficiency to increase firm value.
\end{abstract}

\section{KEY WORDS}

Financial performance, firm value, operational efficiency.

The purpose of financial management of any company in general is to maximize the value of shareholder wealth. Maximizing shareholder wealth means increasing the firm value which is a measure of objective value by the public and an orientation to the company's survival (Harmono, 2020: 1). The valuation of a company is carried out to determine the fair firm value which will later be used as the basis for investors in making decisions (Sukamulja, 2019: 17). Firm value is influenced by various factors internally (company performance, as well as financial distress and issues regarding the company) and externally (inflation, exchange rates, interest rate policies, gross domestic product, and other issues related to the economy as a whole). According to Brigham and Daves (2019: 296), Firm value can be measured using three ratios, namely Price Earning Ratio, Price to Book Value, and Tobin's $Q$. In this study, the variable used as a proxy to measure the firm value is price to book value (PBV) because PBV is a condition of company growth and is considered to better describe the actual situation of a company by looking at the company's equity. The higher the PBV ratio, it means that the market believes in the prospects/future of the company.

Financial performance analysis is an analysis carried out to identify the financial position and performance of the company in the future (Sukamulja, 2019: 59). Financial performance analysis is required by various parties such as company management, investors, creditors, government, suppliers and the public. The company's financial performance is measured by ratio analysis generated from the company's financial statements (Sin Hien and Mariani, 2017: 141). There are five aspects that can be used to analyze financial performance, namely aspects of liquidity, financial leverage, asset management or turnover, profitability, and aspects of market value (Ross et al., 2016: 64). The liquidity aspect shows the company's ability to pay off short-term obligations or how quickly the company converts its assets into cash. Financial leverage describes the proportion of company debt. The higher the proportion of debt for funding the company's assets, the riskier a business will be, but some companies have very high debt funding because it is influenced by business maturity (Sukamulja, 2019: 92). Asset management shows the company's ability to manage assets. Profitability shows the company's ability to earn profits. The market value aspect is a comparison between market value and book value and measures the return for each share of the company. Asset management shows the 
company's ability to manage assets. Profitability shows the company's ability to earn profits. The market value aspect is a comparison between market value and book value and measures the return for each share of the company. Asset management shows the company's ability to manage assets. Profitability shows the company's ability to earn profits. The market value aspect is a comparison between market value and book value and measures the return for each share of the company.

This study uses the company's financial performance variables, namely the company's capital structure and activity management that can affect the value of a company, because these two variables play an important role in increasing the value of a company (Harmono, 2020: 12). When the company is able to carry out operational activities effectively and efficiently, the company can maximize profit because it is able to reduce costs incurred from operational activities, so that the firm value will increase. Based on the theory of capital structure, capital structure analysis is concerned with how capital is allocated in the investment activities of the company's real assets, by determining the capital structure between debt capital and own capital (Harmono, 2020: 137).

Capital structure is a funding between capital and debt in a company which is often calculated based on the relative size of various funding sources. The use of the capital structure must be done efficiently so that the company can obtain funds at a low cost because funding decisions greatly affect the company's performance, especially to maximize shareholder prosperity which is reflected in the company's share price (Astuti and Stella, 2015). Several factors that influence the company's capital structure include business risk, corporate tax position, finance or ability to raise capital, and conservatism or managerial aggressiveness (Brigham and Daves, 2019: 575). Based on the trade off theory, the greater use of debt will lead to financial difficulties or bankruptcy (Wikartika and Fitriya, 2018). Trade off theory is a model of capital structure based on the tradeoff between the advantages and disadvantages of using debt. This theory has the assumption that the company's capital structure is a balance between the benefits of using debt with the costs of financial distress and agency costs (Brigham and Daves, 2019: 574). Debt incurs interest expense which can save tax. Interest expense can be deducted from income so that the profit before tax becomes smaller, thus the tax is also smaller. Companies are likely to face various problems related to bankruptcy when they include more debt in their capital structure. A bankrupt company will find it difficult to retain its customers, suppliers, and employees.

Capital structure has an effect on firm value. When companies are not able to manage their capital structure properly, the risk faced by the company will be higher, so investors will not invest in the company, which will have an impact on the firm value which will decrease. The proxy used to measure the capital structure is the debt to equity ratio which is the ratio between total liabilities and total equity (Brigham and Daves, 2019: 290).Various studies have also been conducted with regard to capital structure and firm value. Research conducted by Tauke (2017) and Hermuningsih (2013) found that capital structure has a significant positive effect on firm value which means that the company has confidence in its prospects in the future, so the company needs additional capital from debt to maximize the firm value. Research conducted by Caundry et al. (2014), Vo and Ellis (2017), and Janor et al. (2017) stated that capital structure has a negative effect on firm value, which means that the higher the level of debt owned by the company, the higher the risk of default faced by the company, and this will cause the firm value to decrease.

Another aspect that needs to be considered is the aspect of the company's operational activities which greatly affect the value of the company, especially for capital-intensive companies such as mining sector companies. Mining activities are usually capital-intensive activities, so a good inventory is very important to ensure production activities in mining companies run with minimum disruption (Siagian, 2015). Mining companies need good inventory management so that opportunity loss can be reduced as little as possible. The amount of inventory must also be maintained in the right amount (optimal) so that the company's working capital stored in the form of inventory can be minimized. Inventory management is at the core of operational performance in many industries (Hancerliogullari et al., 2015). 
Inventory management is part of asset management or activities that can be measured by aspects of activity or efficiency. It is important to note the aspect of activity to be able to determine the level of effectiveness of the company's asset management (Sin Hien and Mariani, 2017: 141). Aspects of activity or efficiency of the company can be measured using several proxies, including receivable turnover, inventory turnover, fixed asset turnover, and total asset turnover (Sin Hien and Mariani, 2017:149). The proxy used in this study is inventory turnover. When the company is able to manage inventory well, the company can increase their income because there is not too much stock of goods in store, so the company is able to reduce storage costs. When the company is able to reduce costs, the company will be more leverage in increasing profits which of course will have an impact on increasing the firm value.

Various studies related to the effect of operational efficiency as measured by using inventory turnover on firm value have also been carried out. Research conducted by Tan et al. (2019) which is proxied by inventory turnover states that inventory turnover has an insignificant positive effect on firm value, Firnanda and Oetomo (2016) find negative results that are not significant while the results of research by Mishra et al. (2013), Rinnaya et al. (2016), Kurniasari (2017)showed a significant positive result between inventory turnover and firm value. The results of this study indicate that the higher the inventory turnover, the higher the firm value because it reflects the company's inventory is selling faster and the company is more efficient in managing inventory (Sukamulja, 2019: 100).

Financial distress (financial difficulty) refers to a situation when a company that has funding sources from debt is unable to pay its obligations to creditors where the financial difficulty will have an impact on bankruptcy (Chamboko et al., 2017). As for the $p$.factor the cause of financial distress from within the company that is cash flow difficulties, large amounts of debt, and losses in the company's operational activities for several years (Ginting, 2017). Financial distress can be proxied using earnings per share (Yayanti and Yanti, 2015), Altman Z-Score (Zhang et al., 2019), and earnings before interest and taxes (EBIT) which shows a negative value for two consecutive years (Istiantoro and Indrawati, 2016). The proxy used in this study to measure financial distress is by using Earnings per Share.

This study uses financial distress as a mediator because based on the trade-off theory when the company is able to manage the risks and costs arising from operational activities, the company will be able to maximize the profits earned, so that the company can increase the firm value. When the company includes more debt in its capital structure, the possibility of bankruptcy costs will be higher, even though the company has a high level of profitability and good activity management, so the company must be able to manage these risks well. Research conducted by Mselmi et al. (2019) shows that financial distress has a significant negative effect on firm value, which indicates that the higher the financial difficulties faced by the company, the lower the firm value will be.

This research was conducted in mining sector companies from 2014 to 2019, because there was a business phenomenon that occurred, among others, fluctuating stock prices, high debt to equity ratios, and cases of termination of employment by a number of mining companies reflecting indications of financial distress. The decline in commodity prices causes a decrease in the financial performance of mining companies that have an impact on the value of mining companies as reflected in the price to book value ratio which has fluctuated from 2014 to 2018. Based on data from Bareksa.com (2016), the overall decline in the mining sector caused the termination of thousands of employees in a number of companies in the mining sector. The losses experienced by mining companies as a whole were also accompanied by an increase in the value of the debt to equity ratio which showed any indication of financial distress will be reflected in a decrease in the company's financial performance and an impact on the firm value, because stakeholders assess the company as having poor performance.

Based on phenomena, issues, and theoretical studies and empirical studies related to Firm Value, and then the hypothesis can be formulated from this research, among others as follows: 
- $\mathrm{H} 1$ : capital structure has a negative and significant effect on firm value;

- H2: operational efficiency has a positive and significant effect on firm value;

- H3: capital structure has a positive and significant effect on financial distress;

- H4: operational efficiency has a negative and significant effect on financial distress;

- H5: financial distress has a negative and significant effect on firm value;

- H6: financial distress is able to mediate the effect of capital structure on firm value;

- H7: financial distress is able to mediate the effect of operational efficiency on firm value.

\section{METHODS OF RESEARCH}

The research design used is quantitative research, using an associative research design. Associative research design is a research design that aims to determine the effect of two or more variables on the dependent variable where this study examines the effect of company financial performance on firm value with financial distress as a mediator (study on mining companies listed on the Indonesia Stock Exchange). The data used in this study is secondary data obtained on the Indonesia Stock Exchange in 2014-2019. This study uses non-participant observation in data collection. The analytical technique used to analyze the data is path analysis. The data processing of this research was assisted by the IBM SPSS statistics 21 program.

The scope of this research includes data on capital structure, operational efficiency, financial distress, and firm value. This research was conducted on mining companies listed on the Indonesia Stock Exchange (IDX) and can be accessed on the website www.idx.co.id. The data obtained are in the form of annual financial reports and other historical reports on the IDX for the 2014-2019 period. The independent variables in this study are capital structure (X1) and operational efficiency (X2) with the dependent variable being firm value $(\mathrm{Y})$ and mediated by the financial distress variable $(\mathrm{Z})$.

The data used in this study are qualitative and quantitative data. Qualitative data in this study are general descriptions of mining companies and interpretations of annual reports, graphs, and images obtained from mining company websites and the Indonesia Stock Exchange. Quantitative data used in the form of share prices (close price), net income, total liabilities, total equity, price to book value, earnings per share, cost of goods sold, and inventories of mining companies in the 2014-2019 period. This study uses a data source, namely secondary data that can be accessed inwww.idx.co.id and finance.yahoo.com.

The population in this study was all companies in the mining sector, totaling 52 companies listed on the Indonesia Stock Exchange in 2014 - 2019. The sample determination carried out in this study was using a non-probability sampling technique, namely purposive sampling technique and obtained as many as 26 samples of companies. mining. The data is obtained in the form of annual reports of mining sector companies using pooled data for 6 years from companies that are sampled. This study uses data collection methods, namely non-participant observation methods and using path analysis techniques.

\section{RESULTS AND DISCUSSION}

The results of table 1 Descriptive Statistics show the total data for each of the Price to Book Value (PBV), Earning Per Share (EPS), Debt To Equity Ratio (DER), and Inventory Turnover (IT) as many as 156 data. From 156 sample data in 2014 to 2019, the minimum PBV value is 0.16 and the maximum value is 9.78 with an average PBV of 1.46 . The EPS value obtained from 156 sample data has a minimum value of 0 and a maximum of 1 with an average of 0.26 . The DER value obtained from 156 sample data, it is known that the minimum DER value is 0.04 and the maximum value is 9.31 with an average DER value of 1.33. The IT value from 156 sample data, it is known that the minimum IT value is 0 with a maximum value of 45.60 with an average IT value of 10.29 . 
Table 1 - Descriptive statistics

\begin{tabular}{llllll}
\hline & $\mathrm{N}$ & Minimum & Maximum & mean & Std. Deviation \\
\hline Price to Book Value & 156 & 0.16 & 9.78 & 1.4606 & 1.3651 \\
\hline Earnings Per Share & 156 & 0.00 & 1.00 & 0.2628 & 0.4416 \\
\hline Debt to Equity Ratio & 156 & 0.04 & 9.31 & 1.3321 & 1.5863 \\
\hline Inventory Turnover & 156 & 0.00 & 45.60 & 10.2899 & 10.1524 \\
\hline Valid N (listwise) & 156 & & & & \\
\hline
\end{tabular}

Source: Secondary Data, 2021.

Testing the coefficient of determination is carried out to find out how much influence the dependent variable can explain by the independent variable. The coefficient of determination is seen from the value of $r$ square in the summary model which is explained in table 2 of the coefficient of determination as follows:

Table 2 - Coefficient of Determination

\begin{tabular}{lllll}
\hline & $\mathrm{R}$ & $\mathrm{R}$ Square & Adjusted R Square & Std. Error of the Estimate \\
\hline Financial Distress & 0.309 & 0.095 & 0.084 & 0.42273 \\
\hline Firm Value & 0.319 & 0.102 & 0.084 & 1.30653 \\
\hline
\end{tabular}

Source: Secondary Data, 2021.

Based on the test results shown in table 2 of the coefficient of determination, it can be seen that the model of the influence of capital structure and efficiency Operational impact on financial distress has an R-Square value of 0.095 which can be interpreted that the variables of capital structure and operational efficiency have an effect of $9.5 \%$ on financial distress, while $90.5 \%$ is explained by other variables outside the variables studied in this study. Likewise, the model of the effect of capital structure, operational efficiency, and financial distress on firm value has an R-Square value of 0.102 which can be interpreted that the variables of capital structure, operational efficiency, and financial distress have an effect of $10.2 \%$ on firm value, while $89.8 \%$ explained by other variables outside the variables studied.

The results of hypothesis testing indicate the significance of the relationship between the research variables. The results used to test the hypothesis are the values contained in coefficients the results of SPSS shown in Table 3 test the following hypotheses.

Table 3 - Hypothesis testing

\begin{tabular}{|c|c|c|c|c|c|c|}
\hline & \multicolumn{2}{|c|}{ Unstandardized Coefficients } & Standardized Coefficients & \multirow{2}{*}{$\mathrm{T}$} & \multirow{2}{*}{ Sig. } & \multirow{2}{*}{ Information } \\
\hline & $\mathrm{B}$ & Std. Error & Beta & & & \\
\hline Capital Structure -> Firm Value & 0.109 & 0.068 & 0.126 & 1,587 & 0.115 & Rejected \\
\hline Operational Efficiency ->Firm Value & 0.035 & 0.011 & 0.262 & 3.350 & 0.001 & Accepted \\
\hline Capital Structure -> Financial Distress & 0.067 & 0.021 & 0.242 & 3.145 & 0.002 & Accepted \\
\hline Operational Efficiency -> Financial Distress & -0.008 & 0.003 & -0.177 & -2.295 & 0.023 & Accepted \\
\hline Financial Distress ->Firm Value & 0.510 & 0.250 & 0.165 & 2.042 & 0.063 & Rejected \\
\hline
\end{tabular}

Source: Secondary Data, 2021.

Hypothesis testing is done by looking at the t value and the sig value resulting from all the variables. If the value of sig. less than or equal to $=0.05$ then $\mathrm{HO}$ is rejected and $\mathrm{H} 1$ is accepted, while if the value of sig. greater than $=0.05$ then $\mathrm{H} 0$ is accepted and $\mathrm{H} 1$ is rejected. The effect of capital structure on firm value has a correlation coefficient value of 0.109 with a t value of 1.587 and a sig value of 0.115 ; these results indicate that the capital structure has a positive but not significant effect on firm value, so the hypothesis $(\mathrm{H} 1)$ is rejected. The results of testing the operational efficiency variable on firm value show the correlation coefficient value of 0.035 and the t-statistic value of 3.350 , and the value of sig. of 0.001 , it shows that operational efficiency has a positive and significant effect on firm value, so the hypothesis $(\mathrm{H} 2)$ is accepted.

The results of testing the effect of capital structure on financial distress show a correlation coefficient of 0.067 and a t-statistic value of 3.145 with a sig. of 0.002 , which means that the capital structure has a positive and significant effect on financial distress, so 
the hypothesis $(\mathrm{H} 3)$ is accepted. The results of testing the operational efficiency variable on financial distress have a correlation coefficient value of -0.008 with a t-statistic value of 2.295 and a $p$-value of 0.023 , which indicates that the operational efficiency variable has a negative and significant effect on financial distress, so the hypothesis $(\mathrm{H} 4)$ accepted. The results of testing the financial distress variable on firm value show a correlation coefficient of 0.510 with a t-statistic value of 2.042 and a sig value of 0.063 , which means that financial distress, has a positive but not significant effect on firm value, so the hypothesis (H5) is rejected.

After knowing the direct effect of each variable, the next step is testing the effect of mediation. The criteria for assessing the mediation effect are based on the Sobel Test scores. The results of testing the effect of mediation are shown in Table 4 of the Sobel Test as follows:

Table 4 - Sobel Test

\begin{tabular}{lllll}
\hline & Test Statistics & Std. Error & $P$-Value & Information \\
\hline $\mathrm{X} 1 \rightarrow \mathrm{Z} \rightarrow \mathrm{Y}$ & 1,718 & 0.019 & 0.086 & Not a mediating variable \\
\hline $\mathrm{X} 2 \rightarrow \mathrm{Z} \rightarrow \mathrm{Y}$ & $-1,620$ & 0.002 & 0.105 & Not a mediating variable \\
\hline
\end{tabular}

Source: Secondary Data, 2021.

Based on the results of the Sobel Test, it shows that the p-value of the effect of capital structure on firm value through the financial distress variable is 0.086 , which means that the financial distress variable is not a mediating variable. T-statistic value of 1.7181 .96 indicates that financial distress does not significantly mediate the effect of capital structure on firm value, so the hypothesis $(\mathrm{H} 6)$ is rejected.

The results of the Sobel Test show that the value of $p$-value the effect of operational efficiency on firm value through the financial distress variable, which is 0.105 with a t-statistic value of -1.6201 .96 which means that the financial distress variable does not significantly mediate the effect of operational efficiency on firm value and the financial distress variable is not a mediator in the effect of operational efficiency on firm value, so the hypothesis $(\mathrm{H} 7)$ is rejected.

Based on these results, it can be explained that operational efficiency has a positive and significant effect on firm value which indicates that the higher the efficiency ratio, the higher the firm value because it reflects the faster the company's inventory is sold and the more efficient the company is in managing inventory. If observed from the side of the capital structure, the company must consider the risk in choosing to finance through debt, in order to be able to increase the firm value. Companies that use larger debt financing, are expected to get a greater return, so that it will have an impact on the firm value which is increasing as well. Based on the trade-off theory, the company must be able to balance the benefits of using debt with the costs of financial distress (financial difficulties) and agency costs. The practical implication that can be given from the results of this research is that this study can be used as consideration for mining companies in determining the level of capital structure that takes into account the balance between benefits and costs and sees the level of operational efficiency to increase firm value.

This study has several limitations, including the scope of the study only examines mining companies listed on the Indonesia Stock Exchange, so that the results of this study have differences when compared to other countries, this study only examines several aspects, namely in terms of capital structure, and efficiency. Operations in assessing financial performance as a factor that affects the firm value, so it cannot be investigated more deeply in other aspects other than these aspects.

\section{CONCLUSION}

The conclusions and research results obtained are that capital structure has no effect on firm value, operational efficiency has a positive and significant effect on firm value, capital structure has a positive and significant effect on financial distress, operational efficiency has 
a negative and significant effect on financial distress, financial distress has no effect on firm value, financial distress is unable to mediate the effect of capital structure on firm value, and financial distress is unable to mediate the effect of operational efficiency on firm value.

The suggestions for further research are, first, the company should also pay attention to external or macro conditions that can affect the company's condition, such as a prolonged economic crisis because this study only examines the company's internal factors. Second, this research can be used as a guide for investors so that when they decide to invest, investors should not only pay attention to one financial aspect, but also pay attention to the overall financial aspect. Third, further research can use other methods to assess the occurrence of financial distress, such as using the Altman Z-Score analysis, Zeta model, Zmijewski model, or using cash flow analysis. Finally, further research can use other variables as mediating variables, such as from the profitability aspect or it can also add moderating variables.

\section{REFERENCES}

1. Aditama, DS 2013. The Effect of Management Ownership, Institutional Ownership, Leverage, and Disclosure of Corporate Social Responsibility on the Value of Manufacturing Companies on the Indonesia Stock Exchange. E-Journal of the Faculty of Economics and Business, University of Muhammadiyah.

2. Afrifa, Godfred Adjapong., and Ernest Gyapong. 2017. Net trade credit: what are the determinants? International Journal of Managerial Finance, 13(3), pp. 246-266.

3. Afriyeni, Endang. 2012. Prediction Model of Corporate Financial Distress. Polybusiness, 4 (2), h: 1-10.

4. Aggrawal, Divya., and Purna Chandra Padhan. 2017. Impact of Capital Structure on Firm Value: Evidence from Indian Hospitality Industry. Indian Journal of Economics. Xavier School of Management.

5. Akhigbe, Aigbe, Anna D. Martin and Laurence J. Mauer. 2014. Influence of Financial Distress on Foreign Exchange Exposure. American Journal of Business, 29 (3/4), pp: 223-236.

6. Al-khatib, Hazem B. et al, 2012. Predicting Financial Distress of Public Companies Listed in Amman Stock Exchange. European Scientific Journal, 8 (15), pp: 1-17.

7. Ananto, Rangga Putra., Mustika, Rasyidah., and Handayani, Desi. 2017. The Effect of Good Corporate Governance (GCG), Leverage, Profitability and Company Size on Financial Distress in Consumer Goods Companies Listed on the Indonesia Stock Exchange. Dharma Andalas Economics \& Business Journal, 19 (1), pp: 92-105.

8. Aprilia, Ratna SR, Zarah Puspitaningtyas, and Aryo Prakoso. 2018. The Effect of Current Ratio, Total Asset Turnover and Debt To Equity Ratio on Price to Book Value with Return on Assets as an Intervening Variable (Study on Consumer Goods Industry Sector Companies on the Indonesia Stock Exchange 2013-2017). Profita: Scientific Communication of Accounting and Taxation, 11 (3), h: 329-358.

9. Asmas, Denny., Hasminidiarty, R. Adisetiawan. 2018. Capital Structure and Variables Affecting It. J-MAS (Journal of Management and Science), 3 (2), h: $237-250$

10. Bareksa.com. 2016. The Mining Sector Index Strengthens 53\% Throughout 2016, the Main Supporter of the $\mathrm{JCl}$ ?, the correlation value of the $\mathrm{JCl}$ and the mining sector index since February has reached 91 percent. Bareksa.com,https://www.bareksa.com/id/text/2016/10/17/index-sector-pertambanganmenguat-53-sepanjang-2016-penopang-utama-ihsg/14103/analysis. Downloaded November 19, 2019.

11. Brealey, Richard. A., Myers, Stewart C., and Allen, Franklin. 2017. Principles of Corporate Finance. Twelfth Edition. New York: McGraw Hill Education.

12. Brigham, E., and Daves, P. 2019. Intermediate Financial Management, Thirteenth Edition. Boston, USA: Cengage Learning, Inc. 
13. Brigita, Gea., and Lena Farida. 2017. The Effect of Capital Structure on Firm Value in the Pulp And Paper Sub-Sector Listed on the Indonesia Stock Exchange (IDX) for the 2010 2014 PeriodLet's FISIP, 4 (2), h: 1-18.

14. Caundry, Naveed Iqbal, Mian Sqib Mehmood, and Asif Mehmood. 2014. Determinants of Corporate Hedging Policies and Derivative Usage in Risk Management Practices of NonFinancial Firms. Munica Personal Repec Archive. 1(2), pp 57562-57610.

15. Chamboko, Richard., Gerald Kadira, Lisho Mundia, and Rumbidzai KT Chamboko. 2017. Mapping Patterns of Financial Distress among Consumers in Zimbabwe. International Journal of Social Economics, 44 (12), pp. 1654-1668.

16. Firnanda, Taurisina., and Oetomo, HeningWidi. 2016. Analysis of Liquidity, Profitability, Solvency, and Inventory Turnover on Firm Value. Journal of Management Science and Research, 5 (2), h: 1-15.

17. Gamez, Manuel Angel Fernandez., Soria, Juan Antonio Campos., Santos, Jose Antonio C., and Alaminos, David. 2019. European Country Heterogeneity in Financial Distress Prediction: An Empirical Analysis with Macroeconomic and Regulatory Factors. Economic Modeling. (online), (https://doi:10.1016/j.econmod.2019.09.050).

18. Ghozali, Imam. 2016. Application of Multivariate Analysis with SPSS Program. Semarang: Diponegoro University Publishing Agency.

19. Ginting, Mitha Christina. 2017. Effect of Current Ratio and Debt to Equity Ratio (DER) on Financial Distress in Property \& Real Estate Companies on the Indonesia Stock Exchange. Journal of Management, 3(2), h: 37-44.

20. Graham, J.R. et al. 2011. Financial Distress in the Great Depression. Financial Management (winter), pp. 821-844.

21. Hancerliogullari, Gulsah., Sen, Alper., and Aktunc, Esra Agca. 2015. Demand Uncertainty and Inventory Turnover Performance an Empirical Analysis of The US Retail Industry. International Journal of Physical Distribution \& Logistics Management. Vol. 46, No. 6/7, pp. $681-708$.

22. Haq, Syahidul., Arfan, Muhammad., and Siswar, Dana. 2013. Financial Ratio Analysis in Predicting Financial Distress (Study on Companies Listed on the Indonesia Stock Exchange). Journal of Accounting, 2 (1), p. $37-46$.

23. Harmoni. 2014. Financial Management: Based on the Balanced Scorecard Approach to Theory, Cases, and Business Research, Edition 1. Jakarta: Bumi Aksara.

24. Hermuningsih, Sri. 2013. Effect of profitability, growth opportunity, capital structure on firm value in public companies in Indonesia. Bulletin of Monetary Economics and Banking. 6(1), pp. 128-148.

25. Istiantoro, Jalu Nasa., and Indrawati, NurKhusniyah. 2016. The Effect of Financial Ratios on Financial Distress Conditions (Study on Textile and Garment Companies Listed on the IDX). Student Scientific Journal of the Faculty of Economics and Business Universitas Brawijaya, 3 (2), p. 1-13.

26. Iswajuni, Iswajuni., Arina Manasia, and Soegeng Soetedjo. 2018. The effect of enterprise risk management (ERM) on firm value in manufacturing companies listed on the Indonesian Stock Exchange year 2010-2013. Asian Journal of Accounting Research, 3 (2), pp. 224-235.

27. Jahanzeb, Agha., Saif-Ur-Rehman., Ahmadimousaabad, Aiyoub., Bajuri, Norkhairul Hafiz., Karami, Meisam. 2014. Trade-Off Theory, Pecking Order Theory and Market Timing Theory: A Comprehensive Review of Capital Structure Theories. International Journal of Management and Commerce Innovations (IMCI), 1(1), pp. 11-18.

28. Janor, Mohd HS BA H., Hamid, Mohamad A., Yatim, Puan. 2017. The Effect of Enterprise Risk Management in Firm Value: Evidence from Malaysian Technology Firm. Management Journal. 49(4), p: 15-35.

29. Kartika, Rizky., and Hasanudin. 2019. Analysis of the Effect of Liquidity, Leverage, Activity, and Profitability on Financial Distress in Public Companies in the Infrastructure, Utilities, and Transportation Sector Period 2011-2015. Journal of Management Science, Oikonomia, 15 (1), p. 1-16. 
30. Khairunnisa, Tanty, Taufik, and Kemas Muhammad Husni Thamrin. 2019. The Effect of Debt to Equity Ratio, Return on Assets, Assets Growth, Current Ratio, and Total Assets Turnover on Firm Value in Food and Beverage Sector Companies Listed on the Indonesia Stock Exchange. Scientific Journal of Business and Applied Management, 14 (1), h: 31-44.

31. Kompas.com. 2016. The Global and National Mining Industry Is at the Edge of the Horn? Kompas.com, Downloaded September 10, 2019.

32. Kurniasari, Mitta Putri. 2017. The Effect of Profitability on Activity Ratios and Leverage on the Value of Manufacturing Companies on the IDX. Journal of Management Science and Research, 6 (8), pp: 1-19.

33. Lakshan, AMI and Wijekoon, WMHN 2013. The Use of Financial Ratios in Predicting Corporate Failure in Sri Lanka. GSTF International Journal on Business Review (GBR), 2(4), pp: 37-43.

34. Manurung, Shinta D., Suhadak, and Nila Firdausi Nuzula. 2014. The Influence of Capital Structure on Profitability and Firm Value: A Study on Food and Beverage Companies listed in the Indonesia Stock Exchange 2010-2012 period. Journal of Business Administration (JAB). 7 (2). Poor. Faculty of Administrative Sciences. Brawijaya University.

35. Mishra, Saurabh., Modi, Sachin B., and Animesh, Animesh. 2013. The Relationship Between Information Technology Capability, Inventory Efficiency, and Shareholder Wealth: A Firm-Level Empirical Analysis. Journal of Operations Management, Vol. 31, No. 6, pp. 298-312.

36. Mselmi, Nada., Hamza, Taher., Lahiani, Amine., and Shahbaz, Muhammad. 2019. Pricing Corporate Financial Distress: Empirical Evidence From The French Stock Market. Journal of International Money and Finance, Vol. 96, pp. 13-27.

37. Osazuwa, Nosakhare Peter., and AyoibChe-Ahmad. 2016. The moderating effect of profitability and leverage on the relationship between eco-efficiency and firm value in publicly traded Malaysian firms. Social Responsibility Journal, 12 (2), pp.295-306.

38. Financial Fervices Authority. 2015. Mining and Forestry Sector Highlights OJK.https://www.ojk.go.id/id/kanal/pasar-modal/ Documents /Pages /Emiten-danPerusahaan-Publik $/ 7 . \% 20$ Highlights $\% 20$ Sector\% 20 Subdivisions \%20Mining\%20 and \%20Kehutanan.pdf. Downloaded September 10, 2019.

39. PwC Indonesia. 2016. PwC: 2015 Was the Worst Year for the Mining Sector,https://www.pwc.com/id/en/media-centre/pwc-in-news/2016/indonesian/pwc--2015-as-the-worst-year-for-sector-pertambangan.html. Downloaded November 20, 2019

40. Rahayu, Maryati., and Bida Sari. 2018. Factors Affecting Firm Value.Ikraith-Humanities, 2 (2), h: 69-76.

41. Rinnaya, IstaYansi., Andini, Rita., and Oemar, Abrar. 2016. The Effect of Profitability, Activity Ratios, Funding Decisions, Investment Decisions on Firm Value (Empirical Study on Manufacturing Companies Listed on the IDX 2010-2014). Journal of Accounting, 2 (2), h: 1-18.

42. Ross, Stephen A., Westerfield, Randolph W., Jordan, Bradford D., Lim, Joseph., and Tan, Ruth. 2016. Fundamentals of Corporate Finance, Second Edition. Asia Global Edition. New York: McGraw Hill Education.

43. Rudangga, I GustiNgurahGede., and GedeMertaSudiarta. 2016. The Effect of Firm Size, Leverage, and Profitability on Firm Value.E-Journal of Management Unud, 5 (7), h: 4394 $-4422$.

44. Setiyawan, Indra., and Pardiman. 2014. The Influence of Current Ratio, Inventory Turnover, Time Interest Earned and Return On Equity on Stock Prices in Manufacturing Companies in the Consumer Goods Sector Listed on the Indonesia Stock Exchange for the 2009-2012 Period. Nominal Journal, 2 (2), pp: 117-133.

45. Shaari, Noor Azizah, Nurfadhilah Abu Hasan, Yamuna Rani Palanimally and Rames Kumar Moona Haji Mohamed. 2013. The Determinants of Derivative Usage: A Study on Malaysian Firms. Interdisciplinary Journal of Contemporary research In Business, 5 (2), pp: 300-316. 
46. Siagian, Togap. 2015. Important Inventory Functions For Mining Companies. (on line), (https://supplychainindonesia.com/new/wp-content/uploads/2015/04/Artikel-TogapSiagian-Fungsi-Penting-Persediaan-for-Perusahaan-Mining.pdf).

47. Sin Hien, Kho and Mariani, Fransiska Ida. 2017. Financial Management Canvas. Jakarta: PT Elex Media KomputindoKompas-Gramedia.

48. Steven et al. 2011. Effects of Financial Distress Condition on the Company Performance: A Malaysia Perspective. Review of Economics \& Finance. Malaysia.

49. Sukamulja, Sukmawati. 2019. Analysis of Financial Statements as a Basis for Making Investment Decisions. Yogyakarta: ANDI with BPFE.

50. Suryowati, estu. 2014. In 2013 the Indonesian economy was only 5.78 percent. Kompas.com,https://economic.kompas.com/read/2014/02/05/1221161/Tahun.2013.Ekon omi.Indonesia.Hanya.5.78.Persen. Downloaded October 10, 2019.

51. Syahrir, Nurwahyuni. 2018. Financial Decisions, Operational Efficiency and Innovation on Improving Financial Performance and Firm Value in Pharmaceutical Companies on the Indonesia Stock Exchange. Thesis. Master Program in Management and Finance, Faculty of Economics and Business, Hasanuddin University, Makassar.

52. Tan, Jianhua., Yan, Lina., and Chan Kam C. 2019. The impact of the logistics service standardization on firm value: Evidence from China. North American Journal of Economics and Finance. (on line), (https://doi:10.1016/j.najef.2019.101134).

53. Tauke, Putri Yuliana., Sri Murni, and Joy E. Tulung. 2017. The Effect of Financial Performance on the Value of Real Estate And Property Companies Listed on the Indonesia Stock Exchange in 2012-2015. EMBA Journal, 5(2), p: 919 - 927.

54. Udenio, Maximiliano., Hoberg, Kai., and Fransoo, Jan C. 2018. Inventory Agility Upon Demand Shocks: Empirical Evidence From The Financial Crisis. Journal of Operations Management, 62(1), pp. 16-43.

55. Utomo, Nanang Ari. 2016. Factors Affecting Firm Value of LQ45 Index Companies on the Indonesia Stock Exchange. Dynamics of Accounting, Finance and Banking, 5 (1), h: $82-$ 94.

56. Vo, Xuan Vinh., and Ellis, Craig. 2017. An Empirical Investigation of Capital Structure and Firm Value in Vietnam. Finance Research Letters, Vol. 22, pp. 90-94.

57. Ware, Stephen J. 2015. Debt, Poverty, and Personal Financial Distress. The American Bankruptcy Law Journal, 89(3), pp: 493-509.

58. Whitaker, Richard B. 1999. The Early Stages of Financial Distress. Journal of Economics and Finance, 23 (2). pp. 123-I33.

59. Widati, Listyorini Wahyu., Pratama, BayuAdhi. 2015. The Effect of Current Ratio, Debt To Equity Ratio, And Return On Equity, To Predict Financial Distress Conditions, Proceedings of the Multi-Discipline National Seminar \& Call For Papers Unisbank (Sendi_U), ISBN: 978-979-3649-81-8.

60. Widnyantari, NLP, and Yadnya, IP 2017. The Effect of Capital Structure, Profitability and Company Size on Firm Value in Food and Beverage Companies on the Indonesia Stock Exchange. E-Journal of Management. 6 (12), p: 6383-6409.

61. Wikartika, Ira., and Zumrotul Fitriya. 2018. Testing Trade off Theory and Pecking Order Theory in the Jakarta Islamic Index. Journal of Business and Management (BISMA) State University of Surabaya. 10(2), h: 90-101.

62. Yayanti et al, 2015. Analysis of the Effect of Liquidity, Operational Efficiency, and Corporate Governance on Financial Distress in Manufacturing Companies Listed on the Indonesia Stock Exchange in the Period 2012-2014. J. of Econ., 20 (1), pp: 154-173.

63. Zaki, Ehab, Rahim Bah, and Ananth Rao. 2011. Assessing Probabilities of Financial Distress of Banks in UAE. International Journal of Managerial Finance, 7 (3), pp: 304-320

64. Zhang, Tiantian., Zhang, Cherry Yi., and Pei, Qifan. 2019. Misconception of Providing Supply Chain Finance: Its Stabilizing Role. International Journal of Production Economics, 213, pp. 175-184.

65. Zhang, Ying, Chong Wu and Xin-Ying Zhang. 2013. Enterprise Financial Distress Prediction Based on BPNN: A Case Study of Chinese Listed Companies. Information Technology Journal, 12 (23), pp: 7684-7690. 